\title{
Genetic Variability, Coefficient of Variance, Heritability and Genetic Advance of Some Gossypium hirsutum L. Accessions
}

\author{
Muhammad Zahir Ahsan ${ }^{1}$, Muhammad Saffar Majidano ${ }^{1}$, Hidayatullah Bhutto ${ }^{1}$, Abdul Wahab Soomro ${ }^{1}$, \\ Faiz Hussain Panhwar ${ }^{1}$, Abdul Razzaque Channa ${ }^{1} \&$ Karim Buksh Sial ${ }^{2}$ \\ ${ }^{1}$ Plant Breeding Section, Central Cotton research Institute Sakrand, Sindh, Pakistan \\ ${ }^{2}$ Agronomy Section, Central Cotton research Institute Sakrand, Sindh, Pakistan \\ Correspondence: Muhammad Zahir Ahsan, Plant Breeding Section, Central Cotton research Institute Sakrand, \\ Sindh, Pakistan. Tel: 92-333-630-7025. E-mail: ahsanzahir@gmail.com
}

Received: November 25, 2014 Accepted: December 25, 2014 Online Published: January 15, 2015

doi:10.5539/jas.v7n2p147 URL: http://dx.doi.org/10.5539/jas.v7n2p147

\begin{abstract}
The present study was conducted in central cotton research Institute Sakrand to analyze the genetic variability, phenotypic, genotypic and environmental coefficient of variation, heritability and genetic advance during summer 2014. In this experiment analysis of variance indicated that significant variation present among the accessions of the upland cotton for all the traits under study. The highest genotypic (GCV) and phenotypic coefficient of variation (PCV) were exhibited by the number of bolls per plant, lint index and seed cotton yield per plant. GCV had similar trend as PCV. High heritability and high genetic advance was observed in the lint index, number of bolls per plant and seed cotton yield per plant. The combination of the high heritability and high genetic advance provide the clear image of the trait in the selection process.
\end{abstract}

Keywords: genetic advance, heritability, ECV, GCV, PCV, coefficient of variability

\section{Introduction:}

Cotton is grown in more than 60 counties worldwide and is an important source of natural fiber globally Cotton. Cotton is also famous for it's named as "queen of fiber plants" and white gold. It is very much necessary to understand the gene action and pattern of inheritance of the traits to choose a suitable breeding methodology for crop improvement (Vineela et al., 2013). Effective breeding program depends upon the variation present in the gene pool for the yield enhancing traits. Selection is effective when magnitude of variability in the breeding population is enough.

Cotton was grown in Sindh Pakistan before 2500 B.C. as Excavations of Mohen Jo Daro showed (Khan, 2003). Cotton is of great importance and has a pivotal role in the economy of the Pakistan. Most of our foreign exchange reserves come directly or indirectly through textile channel from cotton. So sustainable cotton production not only become imperative but we must find out the way to enhance the per acre yield to uplift cotton based economy.

The identification and use of genotype with higher genetic potential is a continuous requirement for the production of better cotton. Efforts are going on to enhance the yield as well as the fiber quality. To achieve these objectives comprehensive studies to understand the genetic mechanism to control the plant characters under different environmental conditions is also necessary.

The present research program was imitated to understand the genetic variation of different upland cotton accessions for yield and related traits. Heritability, Genetic Advance, Genotypic, Phenotypic, Environmental variance and response to the Selection also calculated.

\section{Materials and Methods}

The present study was conducted at Central Cotton Research Institute Sakrand, Sindh, PAKISTAN. The germplasm was comprises of CRIS-664, CRIS-665, CRIS-666, CRIS-667, CRIS-668, CRIS-669, CRIS-670 and CRIS-342. All accessions were sown with $\mathrm{P} \times \mathrm{P}$ distance $30 \mathrm{~cm}$ and $\mathrm{R} \times \mathrm{R}$ distance $75 \mathrm{~cm}$ with three replications. All agronomic practices were kept same for all the replications and treatments. At maturity ten plants were selected from each replication of each accession and data were recorded for plant height, number of bolls per 
plant, boll weight, seed index, lint index, ginning out turn and seed cotton yield per plant.

The data was subjected for analysis of variance (Steel et al., 1997). The genotypic and phenotypic correlations were calculated by Kwon and Torrie (1964) technique. The genetic advance in percentage of mean was calculated by using Falconer (1989) formula.

$$
\begin{gathered}
\text { Genetic Variance }(V g)=\frac{\text { Genotype Mean Square (GMS)- Error Mean Suare (EMS) }}{\text { Number of Replications }(\mathrm{r})} \\
\text { Environmental Variance }=\text { Error MeanSuare }(\text { EMS }) \\
\text { Phenotypic Variance } V p=V g+V e / r
\end{gathered}
$$

Genotypic Phenotypic and Environmental coefficient of Variation was calculated as

$$
G C V \%=\sqrt{\frac{V g}{\bar{x}}} \times 100 ; P C V \%=\sqrt{\frac{V p}{\bar{x}}} \times 100 ; E C V \%=\sqrt{\frac{V e}{\bar{x}}} \times 100
$$

Where, GCV $\%$ = Genotypic Coefficient of variation; Vg = Genotypic Variance; PCV \% = Phenotypic Coefficient of variation; $\mathrm{Vp}=$ Genotypic Variance; ECV \% = Environmental Coefficient of variation; $\mathrm{Ve}=$ Environmental Variance.

Heritability (H2) on Entry Mean Basis was calculated as

$$
H^{2}=\frac{\mathrm{Vp}}{\mathrm{Vg}}
$$

The expected Genetic Advance for each trait was calculated as

$$
G A=K \sqrt{V p} H^{2}
$$

Where, $\mathrm{K}=1.40$ at $20 \%$ selection intensity for trait; $\mathrm{Vp}=$ Phenotypic variance for trait; $\mathrm{H}_{2}=$ Broad Sense Heritability of the trait; Genetic Advance as percentage of mean is calculated as,

$$
G A \%=\frac{G A}{\bar{X}} \times 100
$$

\section{Results and Discussions}

It is clear from the Table 1that significant variation present between the accessions for all the recorded traits. This variation is very important for the plant breeders and selection is effective when magnitude of variability in the breeding population is too enough. Table 2 depicted that the observation between the accessions were highly significant for all the recorded traits. Genotypic variance, genotypic coefficient of variance, phenotypic variance, phenotypic coefficient of variance, Environmental variance, and environmental coefficient of variance, broad sense heritability and response to the selection for eight recorded traits were shown in Table 3. The knowledge of nature and magnitude of the variability among the accessions for the traits is very important prerequisite for making simultaneous selection on more number of traits to make significant improvement in cotton. The analysis of variance indicted that the significant differences present among the accessions for all the traits. It is difficult to separate the heritable and non heritable variation making difficulty in selection for the breeders. Hence it is very necessary for the breeder to separate the heritable portion from the non heritable part to plan for proper breeding program.

Table 1. Mean and Range performance of the traits among the G. hirsutum accessions

\begin{tabular}{llll}
\hline Traits & Minimum & Maximum & Average performance \\
\hline Plant Height (cm) & 111 & 131 & 121.43 \\
No. of Bolls per plant & 25.5 & 39 & 30.69 \\
Boll Weight (g) & 2.96 & 3.774 & 3.51 \\
Seed Index (g) & 6.45 & 8.63 & 7.54 \\
Lint Index (\%age) & 3.47 & 7.06 & 5.10 \\
Ginning Out Turn (\%age) & 30.67 & 46.01 & 39.59 \\
Seed cotton Yield per Plant (Kg) & 83 & 125.42 & 107.03 \\
\hline
\end{tabular}


Table 2. Analysis of variance of the different characters among the accessions of the G. hirsutum

\begin{tabular}{lllllllll}
\hline \multirow{2}{*}{ Source of Variation } & $\begin{array}{l}\text { Degree of } \\
\text { Freedom }\end{array}$ & $\begin{array}{l}\text { Plant } \\
\text { height }\end{array}$ & $\begin{array}{l}\text { No. of Bolls } \\
\text { per Plant }\end{array}$ & $\begin{array}{l}\text { Boll } \\
\text { Weight }\end{array}$ & $\begin{array}{l}\text { Seed } \\
\text { Index }\end{array}$ & $\begin{array}{l}\text { Lint } \\
\text { Index }\end{array}$ & G.O.T.\% & $\begin{array}{l}\text { Seed Cotton Yield } \\
\text { per Plant }\end{array}$ \\
\hline MSS & 7 & $79.63^{* *}$ & $79.63^{* *}$ & $0.304^{* *}$ & $1.77^{* *}$ & $3.98^{* *}$ & $61.61^{* *}$ & $753.34^{* *}$ \\
Error & 14 & 1.19 & 1.38 & 0.0026 & 0.00022 & 0.03 & 0.65 & 2.83 \\
\hline
\end{tabular}

** Highly Significant at $0.01 \%$ level* Significant at $0.05 \%$ level.

Table 3. Mean Sum of squares, genotypic, phenotypic and environmental variance and coefficient of variation, broad sense heritability and response to selection

\begin{tabular}{llllllllll}
\hline Trait & G. Variance & GCV \% & P. Variance & PCV \% & E Variance & ECV\% & $\left(\mathrm{H}^{2}\right)$ & GA & GA as \%age of Mean \\
\hline Plant Height & 130.60 & 9.4 & 131 & 9.4 & 1.19 & 0.89 & 0.9969 & 15.97 & 13.11 \\
Bolls/ Plant & 79.17 & 28.99 & 79.63 & 29.07 & 1.38 & 3.8 & 0.9942 & 12.42 & 40.46 \\
Boll Weight & 0.303 & 15.42 & 0.304 & 15.67 & 0.0026 & 1.4 & 0.9971 & 0.769 & 21.93 \\
Seed Index & 1.76 & 9.4 & 1.77 & 9.4 & 0.00022 & 0.89 & 0.9999 & 1.86 & 24.67 \\
Lint Index & 3.96 & 25.6 & 3.98 & 25.6 & 0.03 & 3.4 & 0.9974 & 2.78 & 54.51 \\
GOT\% & 61.39 & 17.6 & 61.61 & 17.6 & 0.65 & 0.19 & 0.9964 & 10.95 & 27.65 \\
yield/ Plant & 752.39 & 19.7 & 753.34 & 19.8 & 2.83 & 2.01 & 0.9987 & 38.37 & 35.84 \\
\hline
\end{tabular}

Table 4. Potential donor accessions for yield and other recorded traits

\begin{tabular}{lll}
\hline No. & Characters & Potential Donors \\
\hline 1 & Plant Height & CRIS-666, CRIS-669, CRIS-670 \\
2 & Number of Bolls/Plant & CRIS-667, CRIS-670, CRIS-342 \\
3 & Boll Weight & CRIS-667, CRIS-668, CRIS-670 \\
4 & Seed Index & CRIS-666, CRIS-669, CRIS-670 \\
5 & Lint Index & CRIS-665, CRIS-666, CRIS-670 \\
6 & G.O.T. $\%$ & CRIS-665, CRIS-666, CRIS-670 \\
7 & Seed cotton Yield/ Plant & CRIS-667, CRIS-670, CRIS-342 \\
\hline
\end{tabular}

The trait seed cotton yield per plant exhibit the highest genotypic and phenotypic variance i.e 752.39 and 753.34 respectively and followed by the plant height that have genotypic variance 130.60 and phenotypic variance 131 . Lowest genotypic and phenotypic variance was recorded for the traits of boll weight and seed index i.e. 0.303 and 0.304 for boll weight and 1.76 and 1.77 for the seed index respectively. The coefficient of phenotypic, genotypic and environmental variance was also calculated for all the traits under study. The genotypic coefficient of variance was ranged from 9.4\% (Plant Height and Seed Index) to 28.99 (Number of Bolls per Plant). Maximum genotypic coefficient of the variation was observed for the number of bolls per plant $(28.99 \%)$ followed by the lint index (25.6). Phenotypic coefficient of variation also had similar trend as genotypic coefficient of variation. In the present study there was a close correspondence between genotypic and phenotypic coefficient of variation for all the recorded traits it showed that these characters less influenced by the environment. Since the variation depends upon the magnitude of the measuring units of the traits, coefficient of variation is independent of the measuring units so it is more useful in comparing the population. The highest genotypic and phenotypic coefficient of variation observed for the trait number of bolls per plant, lint index and seed cotton yield per plant. It indicates that selection can be applied on the traits to isolate more promising line. Similar type of observations in upland cotton was also reported by the different scientists (Dheva \& Potdukhe, 2002; Preetha \& Raveendran, 2007; Amir et al., 2012; Abbas et al., 2013). Moderate PCV and GCV were observed for the boll weight and ginning out turn. Girase and Mehatne (2002) and Harshal (2010) also noticed the moderate phenotypic and genotypic coefficient of variation for some traits and suggested that these characters can be improved by the vigorous selection. The traits such as plant height and seed index exhibited 
low PCV and GCV which indicated that the breeders should go for source of high variability for these traits to make improvement. Similar type of suggestion was given by Kowsalya and Raveendran (1996), Do Thi Ha An et al. (2006) in their experiments. In a population observed variation is due to both factors i.e. genetics and environmental where as genetic variability is the only heritable from generation to the next generation so the heritability alone does not give an idea about the expected gain in the next generation but it has to be considered in conjunction with the genetic advance. The characters those exhibit maximum heritability and high genetic advance as percentage of mean could be used as powerful tool in selection process such characters are controlled by the additive genes and less influenced by the environment (Panes \& Sukhatme, 1995). The broad sense heritability was highest for all the recorded traits. For efficient selection we cannot solely believe on heritability the combination of high heritability with high genetic advance will provide a clear base on the reliability of that particular trait in the selection of variable entries. The genetic advance as percentage of means for seven traits ranged from $13.11 \%$ to $54.57 \%$. The higher genetic advance as percentage of mean was recorded by lint index (54.57) followed by the number of bolls per plant (40.46), seed cotton yield per plant (35.84), ginning out turn (27.65), seed index (24.67), boll weight (21.97) and plant height (13.11). High heritability and high genetic advance was observed in traits viz. seed cotton yield per plant, lint index and number of bolls per plant. These traits highly reliable during selection process of the accessions. High heritability and moderate genetic advance was found in ginning out turn, seed index and boll weight these results confirmed by the experiment of Muhammad et al. (2004). In this experiment some accessions were identified as potential donors for the crop improvement of different traits (Table 4). From the results of the present study, it can be concluded that direct selection can be done for most of the yield attributing traits since it exhibited high genetic variability and high range of variation. A high PCV and GCV for the characters studied indicated that environment influences on the expression of these traits were minor.

\section{References}

Abbas, H. G., Mahmood, A., \& Ali, Q. (2013) Genetic variability, heritability, genetic advance and correlation studies in cotton (Gossypium hirsutum L.). Int. Res. J. Microbiol., 4(6), 156-161.

Amir, S, Farooq, J., Bibi, A., Khan, S. H., \& Saleem, M. F. (2012). Genetic studies of earliness in Gossypium hirsutum L. IJAVMS, 6(3), 189-207.

Burton, G. W. (1951). Quantitative inheritance in pearl millet (Pennisetum glaucum). Agron. J., 43, 409-417. http://dx.doi.org/10.2134/agronj1951.00021962004300090001x

Dheva, N. G., \& Potdukhe, N. R. (2002). Studies on variability and correlations in upland cotton for yield and its components. J. Indian Soc. Cotton Improv., 148-152.

Do Thi Ha An, \& Ravikesavan, R. (2006). Genetic diversity in cotton (Gossypium sp) (pp. 11-13). National conference on plant sciences research and development. APSI scientist meet, PSG CAS, Coimbatore, India.

Falconer, D. S. (1989). Introduction to Quantitative Genetics (3rd ed.). Logman Scientific and Technical, Logman House, Burnt Mill, Harlow, Essex, England.

Khan, N. U. (2003). Genetic analysis, combining ability and heterotic studies for yield, its components, fibre and oil quality traits in upland cotton (G. hirsutum) (Ph.D Dissertation). Sindh Agric. Univ. Tandojam, Pakistan.

Kowsalya, R., \& Raveendran, T. S. (1996). Genetic variability and D2 analysis in upland cotton. Crop Res., $12(1), 36-42$.

Kwon, S. H., \& Torrie, J. H. (1964). Heritability and interrelationship of two soybean (Glycine max L.) populations. Crop Sci., 4, 196-198. http://dx.doi.org/10.2135/cropsci1964.0011183X000400020023x

Muhammad, I., Muhammad, A. C., Abdul, J., Muhammad, Z. I., Muhammad-ul-Hassan, \& Noor-ul-Islam. (2004). Inheritance of Earliness and other Characters in Upland Cotton. J. Biol. Sci., 3(6), 585-590.

Panes, V. G., \& Sukhatme, P. V. (1995). Statistical methods for agricultural workers (3rd ed., p. 58). ICAR, New Delhi.

Preetha, S., \& Raveendran, T. S. (2007). Genetic variability and association studies in three different morphological groups of cotton (Gossypium hirsutum L.). Asian J. Plant Sci., 6(1), 122-128. http://dx.doi.org/10.3923/ajps.2007.122.128

Steel, R. G. D., Torrie, J. H., \& Dicky, D. A. (1997). Principles and procedures of Statistics. A Biometrical Approach (3rd ed., pp. 400-428). New York: McGraw Hill Book Co. Inc.

Vineela, N., Samba Murthy, J. S. V., Ramakumar, P. V., \& Ratna, K. S. (2013). Variability Studies for Physio 
Morphological and Yield Components Traits in American Cotton (Gossypium hirsutum L.). J. Agric. Vet. Sci., 4(3), 7-10.

\section{Copyrights}

Copyright for this article is retained by the author(s), with first publication rights granted to the journal.

This is an open-access article distributed under the terms and conditions of the Creative Commons Attribution license (http://creativecommons.org/licenses/by/3.0/). 